\title{
Professional accounting bodies' perceptions of ethical issues, causes of ethical failure and ethics education
}

\author{
Beverley Jackling \\ School of Accounting and Law, RMIT University, Melbourne, Australia \\ Barry J. Cooper and Philomena Leung \\ School of Accounting, Economics and Finance, Deakin University, \\ Geelong, Australia, and \\ Steven Dellaportas \\ School of Business, University of Ballarat, Ballarat, Australia
}

\begin{abstract}
Purpose - Given the calls for increased ethics education following recent corporate collapses, this paper aims to examine the significance of ethical issues that challenge the profession and, more specifically, professional accounting bodies.

Design/methodology/approach - The study assesses the perceptions via an online survey of 66 professional accounting bodies worldwide in respect of ethical issues, potential causes of ethical failure and the need for ethics education.

Findings - Respondents identified a number of important challenges including conflicts of interest, earnings management and whistle-blowing. The findings also demonstrate strong support for participation in prescribing the nature of ethics education by members of professional accounting bodies.

Research limitations/implications - The results of this study are based on feedback from 41 per cent of member bodies of the International Federation of Accountants (IFAC). Despite a number of follow-up reminder notices, some regions are under-represented in the responses to the survey distributed to the (then) 160 member bodies of IFAC. Geographic isolation and language limitations contributed to the failure to gain a higher response rate.

Practical implications - The findings demonstrate that professional bodies support ethics education at the pre- and post-qualifying levels of education and a willingness to take an active role in promoting ethics education to their members.

Originality/value - By addressing member bodies' attitudes to ethics education, this paper fills a gap in prior literature that has been restricted to addressing the attitudes of academics, students and business organisations.
\end{abstract}

Keywords Accountancy, Accounting, Ethics

Paper type Research paper

\section{Introduction}

Throughout 2001 and 2002, the financial scandals in the USA and some other countries, such as Australia, dramatically demonstrated how the efficiency of financial markets is based on assumptions of trust and ethical behaviour of corporate managers. The collapse of companies such as Enron, WorldCom and Global Crossing in the USA, 
HIH Insurance and OneTel in Australia, and Parmalat in Italy has led to a loss of confidence by the investing public in the system of financial reporting and accountability. A major factor in this loss of confidence was the unprecedented implosion of one of the then "Big 5" accounting firms, Arthur Andersen, with the loss of 85,000 jobs worldwide and the loss of public trust in the accounting profession that accompanied it. These developments led to the promulgation of the Sarbanes-Oxley Act of 2002 in the USA and similar legislation such as the Corporate Law Economic Reform Program (Audit Reform and Corporate Disclosure) Act 2004 in Australia.

The globalisation and diversification of accounting services, combined with market competition and high profile corporate collapses has drawn attention to the accounting profession and its perceived ethical standards (Ponemon, 1995; Ashkanasy and Windsor, 1997; Armstrong et al., 2003; Leung and Cooper, 2005). Commentators are now questioning, whether the value systems of accounting professionals are strong enough to withstand client and economic pressures that potentially compromise professional judgement (Douglas et al., 1995; Jennings, 2004).

Accounting education is viewed as one potential remedy to address the profession's ethical crisis. Extensive discussion about the role of accounting educators in teaching ethics has been undertaken in the US educational context, including special issues on professionalism and ethics in accounting education (Gaa and Thorne, 2004). Humphrey (2005, p. 342) has indicated that "there remains real scope for reviewing how the international academic accounting profession has responded to such scandals ...". In particular, there is scope to identify the role of professional accounting bodies in providing pre qualification[1] education on ethics, as well as ongoing professional development. Regardless at what stage ethics education takes place, the post-Enron era has presented an opportunity for critical advances in ethics education and one in which professional accounting bodies ought to have a role.

In July 2003, the International Federation of Accountants (IFAC)[2] released a research report entitled, Rebuilding public confidence in financial reporting - an international perspective. The report identified several key weaknesses in organisations from a review of a number of corporate collapses worldwide. The findings of the study included a recommendation for more effective corporate ethics codes as well as the provision of training and support for individuals within organisations to better enable them to face difficult ethical questions (IFAC 2003a, p. 2). Following on from this report IFAC commissioned in 2004 a global research project on approaches to the development and maintenance of professional values and ethics in accounting education programs. This paper draws on that part of the research outcomes from this project addressing the feedback from professional accounting bodies about perceptions of ethical issues facing the profession, the causes of ethical failure and the role of ethics education.

Given the context outlined above, the aim of this paper is to identify professional accounting body perceptions of:

- the likelihood of ethical issues arising in different types of organisations;

- the perceived causes of ethical failure; and

- the role of professional bodies in ethics education.

In particular, this paper considers aspects of the IFAC report commissioned in 2004, addressing perceptions of professional accounting bodies in an environment of 
increasing calls for ethics education and the role that these bodies have in ethics education. The paper also addresses the importance of this enhanced educational role by professional bodies as a means of addressing a range of ethical issues faced by accountants in business and government organisations.

\section{Literature review}

The relevant literature underpinning this research relates to prior research on ethical issues, possible influences on ethical failure and the impact of ethics education on accounting students' ethical sensitivity and awareness. The literature is presented in two sections. Firstly, the literature on ethical issues and possible causes of ethical failure including conflicts of interests, ethical sensitivity and the concept of ethics as moral reasoning is addressed. The second section of the literature review examines the calls for increased ethics education at both pre-qualifying and post-qualification level as a means of improving the moral behaviour of the members of the accounting profession and as one way of restoring the credibility of the profession.

\section{Ethical issues and causes of ethical failure}

Few financial scandals are the result of methodological errors rather, they occur from errors in judgement (Brooks, 2004). This has increasingly been shown in corporate collapses and audit failures associated with organisations such as WorldCom in the USA and HIH Insurance in Australia, where a lack of attention has been given to the ethical and professional values of honesty, integrity, objectivity, due care and the commitment to the public interest before one's own interests (Jennings, 2004; Parker, 2005). The result has been an apparent breakdown in society's belief that accountants act in the public interest. The number of accounting abuses has served as prima facie evidence that something more is needed in terms of accounting ethics (Armstrong et al., 2003). Professional and educational institutions have responded by calling for more ethics education in the accounting curriculum. In "Educating for the public trust" PricewaterhouseCoopers (2003, p. 1), observes that “... at this critical juncture, we choose to focus on accounting education because of the important role it plays in rebuilding public trust".

The collapse of large corporations has serious financial implications for investors, employees and the public (Elias, 2004), giving rise to a credibility crisis (Earley and Kelly, 2004). McPhail (2001, p. 280) has contended that accounting education should contain "an ethics component which attempts to engender a sense of empathy for, and moral commitment to, "the other". Self interest as opposed to a focus on public interest is testament to the distance of the individual from the implications of their decision making in accounting.

The public interest versus self interest. Increased awareness of the public interest is considered to be an important ethical issue that challenges the professional accountant in today's environment. The duty to serve society and the public is known as the "public interest" defined in the Code of Ethics for Professional Accountants as:

... the collective well-being of the community of people and institutions the professional accountant serves, including clients, lenders, governments, employers, employees, investors, the business and financial community and others who rely on the work of professional accountants (APESB, 2006, s.100.1.1)[3]. 
Therefore, the notion of the public interest implies that the professional accountant's responsibility is not exclusive to the needs of an individual client, employer, nor themselves, but all stakeholders who rely on the reports prepared and audited by them.

The accounting profession has been criticised for seeking to protect its self interest rather than the interests of third parties (Lee, 1995). Self interest threats arise where there is a conflict of personal interest and the interests of those served by the professional, leading to the possibility of compromise. Parker (1994) observed that the public interest is readily declared, but the private interest remains submerged, yet powerful. The conflict between the public interest and self interest is increasingly under scrutiny, with highly publicised corporate collapses and alleged accounting failures. Consequently, the accounting profession has been taken to task for a variety of ethical issues, ranging from a lack of independence by public accountants on audit engagements, engaging in creative accounting, tax fraud and evasion, and conflicts of interest, as well as a failure of the duty of care towards shareholders and the public.

Ethical sensitivity of practitioners. Ethical sensitivity is based on the premise that a dilemma is recognised as an ethical issue, or at least containing an ethical component. Empirical research relates to ethical sensitivity (ability to identify and recognise ethical issues when they arise) and moral reasoning judgement (relating to how and why ethical decisions are made). If professionals are sensitive to ethical issues, then the decision-maker is likely to use moral dimensions in resolving the dilemma, rather than take a heuristic approach such as profit maximisation (Hooks and Tyson, 1995). Therefore, the professional must recognise the ethical component in a dilemma before an ethical decision can be made (Armstrong et al., 2003; Jones, 1991). The problem for professionals is that ethical issues are often hidden (Bebeau et al., 1985) and they often lack the ethical sensitivity to recognise ethical dilemmas when they arise.

The accounting profession relies extensively on ethical behaviour with accountants and auditors regarded as "moral agents" of corporations and societies (Schweiker, 1993, p. 232). Although codes of ethics are an important device, they do not guarantee members of the profession comply with the code. More important is the recognition that ethics and ethical behaviour is underpinned by moral reasoning.

Ethics as moral reasoning. The most widely known work in the area of moral reasoning is that of Kohlberg (1969), who developed the theory of cognitive moral reasoning and development. Kohlberg's theory is concerned with how judgements are made and why one formulates judgement (Kohlberg, 1969). Generally higher levels of moral reasoning are indicative of higher ethical standards. In the case of auditors, researchers discovered a number of positive associations. For example, Ponemon (1993a) found that as auditors' level of moral reasoning increase, so do their assessments of audit risk and prediction regarding the detection of a material accounting error. Generally, prior research has found that auditors with higher levels of moral development rely more on judgement and less on technical standards for problem resolution (Ponemon and Gabhart, 1990; Sweeney and Roberts, 1997). Furthermore, auditors with high moral reasoning tend to be more resistant to client pressure, whereas auditors with lower levels of moral reasoning respond to economic variables and self interest (Bernardi, 1994; Windsor and Ashkanasy, 1995; Ashkanasy and Windsor, 1997).

While auditors demonstrate positive associations with a higher level of moral development, the findings from comparative studies are not as encouraging. A number of studies have examined and compared the moral judgement levels of various groups, 
including the accounting profession. According to Gaa (1995), the moral reasoning of accountants differs in a number of ways from both the general population and from other occupational groups. In general, empirical evidence indicates that accounting professionals do not compare favourably with similar occupational groups or the adult population (Armstrong, 1987).

Armstrong et al. (2003, p. 10) indicate that the educators "set the stage for ethical behaviour by increasing moral sensitivity, moral reasoning and moral motivation". The next section reviews the calls for increased ethics education in the light of the loss of public confidence in business following corporate scandals referred to above.

\section{Calls for increased ethics education}

The special edition of Issues in Accounting Education (Gaa and Thorne, 2004) highlighted that ethics education at university does not appear to have been given the level of importance it warrants. Recent studies from an industry perspective such as PricewaterhouseCoopers (2003, p. 35) have also identified that ethics is not a consistent and integrated part of the education of most accounting students and therefore this represents a gap in education between pre-entry and continuing professional education.

Calls for the expansion of ethics education in the business curricula, however, are not new. Some, such as Giacomino (1992), have attributed the need for ethics education to the general moral decline in society in recent decades. Many have argued that business education providers have a responsibility to contribute to the ethical development of learners (Bok, 1988; Gandz and Hayes, 1988). Smith (2003, p. 49) claims "the leadership of the accounting profession, as well as academe, has a responsibility to inculcate in practitioners and students ethical behaviour and personal integrity".

Enriching ethics in accounting education and improving the moral behaviour of its members is viewed as one way to restore the credibility of the profession (McPhail, 2001). Ethical or moral competency should be regarded by business and society as an accepted attribute of an accounting professional and arguably the starting place for developing such attributes is ethics education.

Ethics education in the curriculum. Until recently, few studies in accounting education have assessed the effect of ethics intervention in the accounting curriculum. Bernardi (2004, p. 145) suggests that, at best, ethics has been a secondary area of interest of accounting academics and therefore has not been perceived to be an important area of accounting research or teaching. This reluctance can be traced to the diversity of opinion as to whether or not ethics can be effectively taught at university level (Stape, 2002), or whether ethical development takes place while practically resolving ethical dilemmas on the job (Petrecca, 2002).

Empirical studies investigating the effects of ethics subject material which were integrated into existing accounting courses have produced mixed results (St Pierre et al., 1990; Armstrong, 1993; Armstrong et al., 2003; Ponemon, 1993b; Shaub, 1994; Welton et al., 1994). Armstrong (1993) did stress that the positive effect of ethics education on students' moral development was beyond that which is expected to occur naturally. Therefore, an understanding of the factors that are associated with elevated levels of moral development is of practical value in ensuring that accountants always adhere to high moral standards in their exercise of moral judgement (Thorne, 1999).

Continuing professional development - challenging the organisational climate. Prior research suggests that when ethics is incorporated in the accounting curriculum it does 
influence students' professional attitudes (Clikeman and Henning, 2000). However, it is questionable whether this education has an ongoing benefit once graduates enter the workforce. Prior research suggests that one important factor that influences ethical behaviour of employees is the ethical climate of the organisation (Sinclair, 1993, Wimbush et al., 1997). More specifically ethical behaviour of subordinates has been shown to be strongly influenced by their supervisors thus suggesting that the ethical climate of an organisation reflects the climate that management adopts (Wimbush and Shepard, 1994).

Some studies have suggested that the culture and values of firms have an important negative influence on accountants' behaviour (Clikeman, 2003; Appelbaum et al., 2005) and as such have the potential to override the lessons in professionalism and public responsibility provided by educators. An organisation's ethical climate is viewed as part of the organisational culture and Victor and Cullen (1988) postulate that once part of an organisation, employees learn how to behave through the formal and informal socialisation environment. As part of the socialisation process employees learn which values are held in high esteem and rewarded by the organisation culture.

The importance of the work environment on ethical behaviour raises the issue of the role of professional accounting bodies in not only providing professional accreditation courses for university graduates, but also the provision of ongoing professional development activities in ethics education. The PricewaterhouseCoopers (2003, p. 7) study acknowledges that no longer can pre-entry and continuing professional education be addressed in silos, recommending that college and professional educators must work together to improve the quality of the profession.

In an attempt to gain a greater appreciation of the professional accounting bodies' commitment to ethics education, this study investigates their views as IFAC members. The study examines member body views' on the ethical issues that face accountants in differing types of business enterprises, the causes of ethical failure and their views on the role of professional bodies in ethics education, including placement of ethics education in the curriculum.

\section{Method}

As part of a larger IFAC (2006) project, this paper reports on the first of two surveys that were distributed by the project team to support the development of International Education Standard (IES) 4: Professional values, ethics and attitudes (IFAC, 2003b). These surveys, issued to member bodies of IFAC, aimed to identify the current practices and beliefs in respect of ethics education and the development programs at pre- and post-qualifying levels. The paper specifically addresses member bodies' perceptions of the likelihood of ethical issues occurring in various types of enterprises, the factors contributing to ethical failure and perceptions of ethics education.

The incorporation of perceptions of ethical issues across various types of enterprises is motivated by prior literature which indicates that different ethical issues may be dominant in some enterprise settings and linked with the organisational climate of the organisation (Wimbush et al., 1997). For instance, the work of Deshpandé (1996) examined the ethical climate and the link between success and ethical behaviour in non-profit organisations. The findings of the study showed that ethical improprieties committed in not-for-profit organisations in the USA in the 1990s had to some extent 
eroded public trust in charitable organisations, despite their perceived "caring" organisational role in society.

Others have suggested that it may be more difficult for business enterprises to adhere to ethical practices than professional practices. For example, Gardner (2007 p. 54) indicates that if professionals do not act according to recognised standards (codes and sanctions of ethical behaviour), they can be expelled from their professional guild. He argues that in contrast business enterprises lack such a model of ethical compliance, as the main goal is profit making, with professional standards a "vocational option". Therefore, certain types of ethical issues, such as self interest as opposed to public interest, may be of greater importance for business enterprises than, for example public accounting practices where there are more clearly defined sanctions for unethical behaviour. However, the range of corporate collapses lends support to the need to examine whether there are perceived differences in ethical issues in this type of organisational structure compared with others such as government and not-for-profit enterprises.

Given the ethical codes, control mechanisms and sanctions for professions, it would be anticipated that ethical issues would be perceived to be less important in public accounting practices. However, the demise of Andersen one of the world's largest public accounting practices in 2001, suggests that various ethical issues may be of significance for this type of enterprise, particularly given the changing responsibilities and roles of practitioners. Therefore, this study examines the possible differences in perceptions of professional bodies of ethical issues related to public accounting practices, business entities and government/not-for-profit organisations.

\section{Participants}

At the time of the study there were 160 member bodies of IFAC in 120 countries throughout the world. Each member body was sent a letter with a detailed description of the objectives of the study and the instructions to access the online survey forms. The online survey became accessible to respondents from November 2004 till the end of January 2005. Four follow up requests were sent to non-respondents to maximize the response rate. Member bodies experiencing difficulties in accessing the online surveys because of their geographical remoteness were sent a Word document version of the survey, with the opportunity to return the document via emails. Five postal surveys were also sent to member bodies in countries where it was impracticable to receive and send e-mails.

At the survey cut-off date, 66 member bodies had responded to the survey, representing 41.25 per cent of all professional accounting member bodies of IFAC. Relying on IFAC's geographical classification of member bodies (Americas, Asia Pacific, Middle East and Sub Saharan Africa and Europe) Table I indicates that there was a reasonable geographical spread represented by the responses, with particularly

Table I.

Distribution of professional body responses by geographic region based on classification of regions by IFAC

\section{Geographic region}

Americas

Asia/Pacific

Middle East/African subcontinent (MAS)

Europe

Total
Response rate No. surveyed No. of responses (percentage)

$\begin{array}{rrr}33 & 7 & 21 \\ 27 & 15 & 56 \\ 39 & 12 & 31 \\ 61 & 32 & 52 \\ 160 & 66 & 41\end{array}$


high response rates achieved from the Asia Pacific region (56 per cent) and Europe (52 per cent).

The respondents to the survey held senior positions within their professional accounting body. For instance, 19 of the 66 (29 per cent) respondents held the position of chief executive officer while a further 35 (53 per cent) identified themselves as chief education officer, chairman, technical director or executive director.

The results of the study have been analysed using the Statistical Package for Social Sciences version 14 (SPSS) and relevant key findings are reported in the next section of this paper.

\section{Results}

This section discusses the research findings in relation to perceptions of IFAC member bodies of the likelihood of ethical issues, factors contributing to ethical failure and the profession's role in ethics education.

\section{Perceptions of ethical issues}

In order to foster the relevance (of topics and standards) of ethics education for the member (professional) bodies of IFAC, the first stage of the analysis was to identify the perceptions regarding the types of ethical issues faced by accountants. Respondents were asked their views on the likelihood of the occurrence of different types of ethical issues in public accounting practices, business entities and government and not-for-profit organisations. While much of the literature on ethical failure in accounting has concentrated on the implications for accountants in the "Big 4" and business entities (PricewaterhouseCoopers, 2003), this study sought views on ethical issues that were perceived to confront a range of business types including government and not-for-profit organisations. This approach was based on the earlier literature that suggests ethical issues may be perceived differently in different types of organisations.

The items included in the survey on types of ethical issues were based on prior literature that has highlighted the importance of self interest as an influence on (un)ethical behaviour in the workplace (Appelbaum et al., 2005), conflicts of self interest and familiarity threats. Further, ethical issue items were derived in the main from the literature on ethics and also from the categories of ethical threats identified in the conceptual framework underpinning the IFAC (2005, p. 8) Code of ethics for professional accountants.

The respondents were asked to rank the probability levels of ethical issues as: "not likely" (1); "somewhat likely" (2); "likely" (3); and "very likely" (4) for each of three types of enterprise - public accounting practice; business entities and government/not-for-profit enterprises. The ethical issue items were tested for internal consistency. The Cronbach's $\alpha$ tests for each set of questions revealed that all items were above 0.8 , indicating good internal consistency for the items used in the study (Hair et al., 2006). The overall responses, analysed by type of business enterprise are shown in Table II.

The results shown in Table II indicate that the ethical issues perceived to be most likely to occur in public accounting practices and business entities were conflicts of interest (including self interest), with mean scores of 3.2 representing a value between 3 "likely" and 4 "very likely". This finding is consistent with the prior study of Wimbush et al. (1997) who found that organisational climate (where members look out for their own self interests, often at a cost to others) was most closely related to unethical behaviour. 


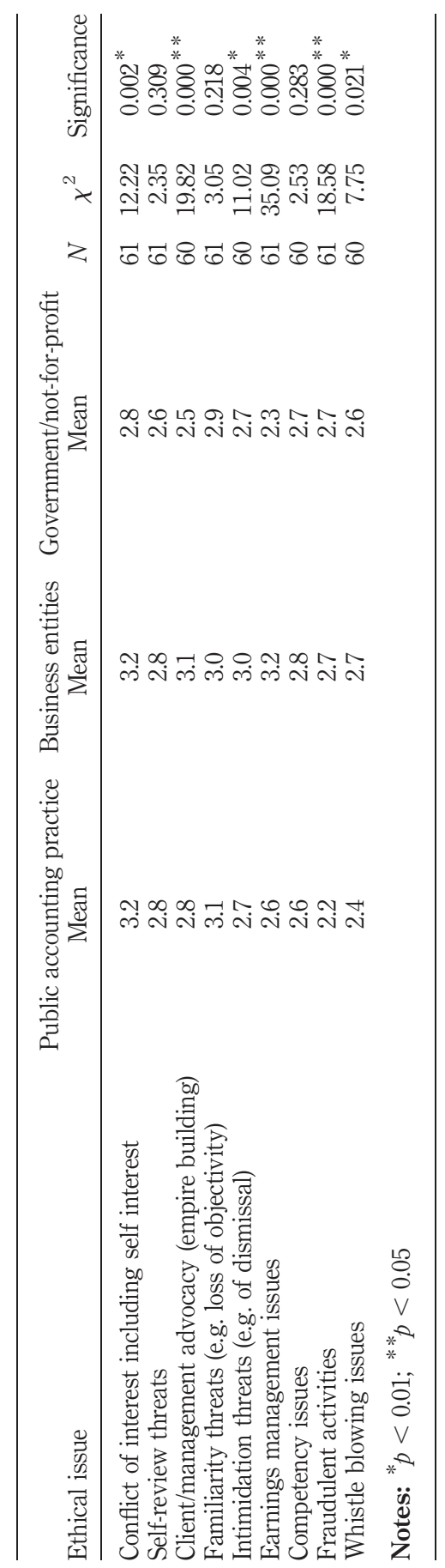

Table II.

Perceptions of the

likelihood of ethical issues by type of enterprise 
Self interest is often endorsed, objectively or subjectively, by the lack of organisational policies or the failure to enforce laws concerning this type of behaviour (Wimbush and Shepard, 1994)[4]. The most highly rated ethical issue for government and not-for-profit organisations was "familiarity threats" with a mean of 2.9 while, self interest threats had a mean of 2.8 for these types of enterprises.

In business entities, earnings management rated equally highly as self interest issues, both with means of 3.2. The emerging significance of earnings management has been seen as a key factor in many corporate collapses and occurs when the "true" financial information is concealed by adjustments to the accounts to show a desired outcome. Earnings management can involve re-stating accruals, mis-classification of accounts between revenue and capital items, smoothing the accounts to take advantage of temporary financial situations and manipulating accounts to show optimistic forecasts.

Further, statistical analysis was undertaken of these results to determine if there were significant differences in the perceptions of the likelihood of ethical issues by type of enterprise. The non parametric Kruskal-Wallis test was used to evaluate the differences between the three types of enterprises for each of the ethical issues (Gravetter and Wallnau, 2004). The outcome of the test for each ethical issue is shown in Table II.

The results indicate that for six of the nine ethical issue items, there were significant differences by type of enterprise. Earnings management issues (mean of 3.2) and client/management advocacy issues (mean of 3.1) were perceived to be significantly more likely for business entities compared with public accounting firms and government/not-for-profit entities. Similarly, fraudulent activities were perceived to be more of an ethical issue in business entities (mean of 2.7) and government/not-for-profit entities (mean of 2.7) than in public accounting firms (mean of 2.2). It is of interest that overall, the respondents were less inclined to view ethical issues more likely to occur in public accounting practices than in business entities.

\section{Perceptions of the causes of ethical failure}

This study also sought feedback from member bodies of the accounting profession about the causes of ethical failure. Respondents were asked to express their views by selecting whether they: "strongly disagreed" (1); "disagreed" (2); "agreed" (3) or "strongly agreed" (4) with a series of statements about possible causes of ethical failure in business. The mean responses provide some indication of the degree of concern about ethical failures. Results of the analysis shown in Table III suggest that representatives of responding professional bodies were aware of the significance of many of the ethical issues which may contribute to ethical failures.

\begin{tabular}{|c|c|c|c|}
\hline Ethical failure factor & $N$ & Overall mean & \\
\hline 1. Self interest & 66 & 3.3 & \\
\hline 2. Failure to maintain objectivity and independence & 66 & 3.3 & \\
\hline 3. Inappropriate professional judgment & 66 & 3.0 & \\
\hline 4. Lack of ethical sensitivity & 65 & 2.9 & \\
\hline 5. Improper leadership and ill-culture & 64 & 2.8 & \\
\hline 6. Failure to withstand advocacy threats & 65 & 2.8 & Table III. \\
\hline 7. Lack of competence & 65 & 2.6 & Perceptions of factors \\
\hline 8. Lack of organisational and peer support & 65 & 2.4 & contributing to ethical \\
\hline 9. Lack of professional body support & 64 & 2.0 & failure \\
\hline
\end{tabular}


Table III highlights the professional bodies' perceptions on the causes of ethical failures by individual professional accountants. The extent to which respondents agreed with the statements appearing in Table III are shown in rank order from highest to lowest. The results show that "self interest" and a "failure to maintain objectivity and independence" with a mean score of 3.3, were considered to be the most likely factors to cause ethical failure (50-60 per cent of respondents). The importance of organisational climate and peer support was also considered likely to be a cause of ethical failure (overall mean $=2.4$ ). This finding is consistent with Wimbush and Shepard (1994) where ethical behaviour of subordinates was shown to be strongly influenced by their supervisors, suggesting that the actual behaviour of top management reinforces the way lower-level employees act and indeed sets the scene for the organisational climate. It is noted that the level of professional body support was rated as an "unlikely" factor contributing to ethical failure (overall mean $=2$ ).

Overall, each of the ethical issues listed in Table III was recognized as a likely cause of ethical failure, with the exception of the item "professional body's support". The Kruskal-Wallis test for differences between geographic regions and the results shown in Table IV indicate that there were no significant differences between regions for each of the items of potential source of ethical failure. The results do suggest, however, that professional bodies regardless of their geographic region, generally agree on the importance of the ethical failure items provided in the study.

The ethical issues cited in the survey are typical issues which might be faced by many in organisations and in professional practices. Ethical issues such as conflict of interest and failure to maintain objectivity and independence are not unique to the accounting profession. As such, opportunities for wider consultation and collaboration with professional bodies from other discipline areas would be useful in resolving the crisis of confidence that has developed from a number of corporate collapses in recent times.

Perceptions of ethics education

Role of professional bodies in teaching ethics. Feedback from professional bodies was sought on the timing of ethics education including compulsory units, integrated approaches, including dedicated and integrated units in pre-qualifying programs. Table $\mathrm{V}$ shows the ranking of agreement ( 1 - strongly disagree; 4 - strongly agree) by

Table IV.

Perceptions of factors contributing to ethical failure - by geographical region

\begin{tabular}{|c|c|c|c|c|c|}
\hline \multirow[b]{2}{*}{ Ethical failure factor } & \multicolumn{5}{|c|}{ Geographical region } \\
\hline & Americas & Asia/Pacific & MAS & Europe & $\chi^{2 *}$ \\
\hline Self interest & 3.1 & 3.5 & 3.5 & 3.2 & 2.315 \\
\hline Failure to maintain objectivity and independence & 3.0 & 3.6 & 3.5 & 3.2 & 5.413 \\
\hline Failure to withstand advocacy threats & 2.9 & 2.9 & 3.0 & 2.8 & 1.936 \\
\hline Lack of competence & 2.1 & 2.7 & 2.4 & 2.8 & 2.303 \\
\hline Lack of ethical sensitivity & 2.6 & 2.9 & 2.8 & 3.0 & 3.226 \\
\hline Inappropriate professional judgment & 2.9 & 3.2 & 2.9 & 3.0 & 1.356 \\
\hline Lack of professional body support & 1.4 & 1.9 & 2.4 & 1.9 & 4.130 \\
\hline Lack of organizational and peer support & 2.1 & 2.4 & 2.5 & 2.4 & 1.214 \\
\hline Improper leadership and ill-culture & 2.9 & 3.1 & 2.8 & 2.7 & 6.055 \\
\hline
\end{tabular}

Note: *Non of $\chi^{2}$ results were statistically significant 


\begin{tabular}{|c|c|c|c|c|}
\hline Statement about ethics education & $N$ & Mean & $\mathrm{SD}$ & \\
\hline $\begin{array}{l}\text { Professional accounting bodies have a significant } \\
\text { role in ethics development }\end{array}$ & 66 & 3.8 & 0.432 & \\
\hline Ethics should be learned as part of the pre-qualifying & & & & \\
\hline programs . & 65 & 3.5 & 0.614 & \\
\hline $\begin{array}{l}\text { The professional body should prescribe the nature of } \\
\text { ethics education for accountants }{ }^{\text {a }}\end{array}$ & 65 & 3.4 & 0.638 & \\
\hline $\begin{array}{l}\text { Ethics should be learned just like other technical } \\
\text { accounting skills }\end{array}$ & 65 & 3.2 & 0.795 & \\
\hline Ethics can be learned other than in the workplace ${ }^{\text {a }}$ & 65 & 3.1 & 0.609 & \\
\hline $\begin{array}{l}\text { Ethics should be integrated within other relevant } \\
\text { units of study in pre-qualifying programs } \\
\text { Ethics should be a dedicated unit and integrated } \\
\text { within other units of study in pre-qualifying }\end{array}$ & 65 & 3.1 & 0.781 & \\
\hline programs & 63 & 3.1 & 0.692 & \\
\hline $\begin{array}{l}\text { Ethics should be learned as part of general education } \\
\text { prior to entry level }\end{array}$ & 66 & 3.0 & 0.823 & \\
\hline $\begin{array}{l}\text { Ethics should be a compulsory foundation unit in } \\
\text { pre-qualifying programs }\end{array}$ & 65 & 3.0 & 0.795 & \\
\hline $\begin{array}{l}\text { Ethics should be learned as a dedicated unit in } \\
\text { pre-qualifying programs }\end{array}$ & 65 & 2.7 & 0.713 & $\begin{array}{r}\text { Table V. } \\
\text { Perceptions of ethics }\end{array}$ \\
\hline Note: ${ }^{a}$ Reverse scored items & & & & education \\
\hline
\end{tabular}

professional bodies with statements about ethics education, from highest to lowest ranked responses.

Professional bodies believe that they have a significant role in the professional ethics development of their members as they rated "agree" to "strongly agree" (mean $=3.8)$ regarding their role in ethics development. Furthermore, the respondents believed that professional bodies should be positioned to prescribe the nature of ethics education for accountants (mean $=3.4$ ). There was acknowledgement by the professional bodies that ethics is capable of being taught other than in the workplace. This result supports prior research that social and behavioural skills linked to ethics education can be learned in educational programs (Armstrong, 1993; Thorne, 1999; Earley and Kelly, 2004).

With a commitment to develop professional values, ethics and attitudes for members, professional bodies have a strong belief that ethics should be learned as part of the pre-qualifying programs (mean $=3.5$ ) and they also agreed ethics should be a compulsory foundation unit (mean $=3.0$ ) in the pre-qualifying program. This finding is consistent with the recommendation of Windsor (cited in Swanson, 2005, p. 250) who favoured a compulsory ethics unit prior to graduation, rather than topics "scattered across the curriculum so thinly ... that the message falls apart". There is also more common agreement that ethics should be learned as a dedicated unit and also integrated within other units of studies in pre-qualifying programs (mean $=3.1$ ).

\section{Discussion and conclusion}

This paper sought to examine the perceptions of professional accounting body members of IFAC about ethical issues, causes of ethical failure, and the role of 
professional bodies in ethics education. The results demonstrate that conflict of interests, including self interest threats, are perceived by professional bodies to be the most likely occurring ethical issues faced by accountants in public accounting practice and business entities. These issues were also relatively significant in the government and not-for-profit sectors. This finding is consistent with prior research that has shown that an organisational climate where members of an organisation look out for their own self interest is a major source of unethical behaviour (Wimbush et al., 1997; Appelbaum et al., 2005).

From the findings, key ethical risks suggested are: self interest, failure to maintain objectivity and independence, improper leadership and poor organisational culture, lack of ethical courage to do what is right, lack of ethical sensitivity and failure to exercise proper professional judgement. Given these areas of ethical risk, the challenge is for professional bodies to work with accounting academics in universities and colleges to improve the ethical knowledge and behaviour of accountants in the workplace. Earnings management has increasingly become an issue for the accounting profession and the results of this study demonstrate that professional bodies rated this issue highly, particularly for accountants in business entities. Of interest is that in this instance earnings management was perceived to be less of an issue for accounting practices and the government or not-for-profit sectors.

The responding professional bodies were clearly committed to a significant role in ethics development and acknowledged that ethics should be part of the accounting curriculum just like other technical accounting skills. There was also acknowledgment that appropriate ethics education means requiring learners to think critically before making decisions with ethical implications thus going beyond traditional textbook approaches that have traditionally relied on codes of professional conduct as the benchmark for determining ethical behaviour (Jennings, 2004, p. 24). In terms of the delivery of ethics education, there was a strong consensus that ethics should be learned as part of the pre-qualifying programs and that ethics education should be a dedicated unit as well as integrated within other units of study in pre-qualifying programs. This finding is consistent with recent calls for a compulsory unit of accounting in the curriculum in the USA (Swanson, 2005).

From this study it is evident that professional bodies are supportive of ethics being part of post qualification studies, given that there was strong support for ethics to be a part of continuing professional development and career development across all geographical regions. The findings of this study also reinforce the view of the PricewaterhouseCoopers (2003) study that recommended that college and professional educators must work together to be efficient and create credibility with learners. Given that the greatest challenges to ethical behaviour are arguably related to the culture and values of firms (Clikeman, 2003; Appelbaum et al., 2005), the professional bodies are best placed to promote ethical behaviour in the workplace via membership and ongoing educational development of members. It has been suggested that subcultures can act as corporate watchdogs (Sinclair, 1993). Therefore, if professional bodies can make a major contribution to improving the ethical climate in organisations via continuing professional development of members, they may assist more readily in the restoration of public confidence in business following the wave of corporate scandals around the world. 
There are some limitations to this study that may have implications for interpreting the results. First, the results examine the feedback from representatives of member bodies of IFAC and do not incorporate feedback from other stakeholders in ethics education, such as academics and industry representatives. Another limitation is the size of the sample. At the time the study was conducted there were 160 member bodies of IFAC. Although a 41.25 per cent response rate is generally considered adequate, the researchers believe that a better response rate from this population would have strengthened the conclusions drawn from the study. Every effort was made to increase the response rate with four follow up reminders to member bodies. However, geographic isolation and language limitations (given the survey was distributed in English) contributed to the failure to gain a higher response rate from some member bodies of IFAC. It should also be noted that the response rates for the Americans and the Middle-East/African subcontinent regions were lower than the response rates achieved for Asia/Pacific and Europe, which may impact on the interpretation of the findings.

Despite these limitations it is concluded that there is positive feedback in relation to the need and scope of ethics education for accountants by professional bodies that have been surveyed internationally. Moreover, the results of this study indicate that there is a general belief that ethics education should incorporate a range of ethical issues that can assist in the education of accountants in public practice, business entities, the government and not-for-profit sectors.

\section{Notes}

1. Pre-qualification education means the period before qualification as an individual professional accounting member of an IFAC member body.

2. IFAC is the global organisation for the accountancy profession. It works with its 163 member organisations in 120 countries to protect the public interest by encouraging high quality practices by the world's accountants. IFAC members represent 2.5 million accountants worldwide employed in public practice, industry and commerce, government, and academe: www.ifac.org/About/

3. The Code of Professional Ethics for Professional Accountants is jointly issued by the three Australian professional accounting bodies: CPA Australia, Institute of Chartered Accountants Australia and the National Institute of Accountants.

4. Examples of these conflicts are provision of services which directly or indirectly compete with clients or employers, pursuing private contracts with suppliers or customers of clients or employers and deriving personal gain from one's position or from the information obtained during the performance of professional services.

\section{References}

APESB (2006) Code of Ethics for Professional Accountants. APES 110, CPA Australia, Institute of Chartered Accountants in Australia. National Institute of Accountants.

Appelbaum, S.H., Deguire, K.J. and Mathieu, L. (2005), "The relationship of ethical climate to deviant workplace behaviour", Corporate Governance, Vol. 5 No. 4, pp. 43-55.

Armstrong, M.B. (1987), "Moral development and accounting education”, Journal of Accounting Education, Vol. 5, pp. 27-43.

Armstrong, M.B. (1993), "Ethics and professionalism in accounting education: a sample course", Journal of Accounting Education, Vol. 11, pp. 77-92. 
Armstrong, M.B., Ketz, J.E. and Owsen, D. (2003), "Ethics education in accounting: moving toward ethical motivation and ethical behavior", Journal of Accounting Education, Vol. 21, pp. 1-16.

Ashkanasy, N.M. and Windsor, C.A. (1997), "Personal and organisational factors affecting auditor independence: empirical evidence and directions for future research", Research on Accounting Ethics, Vol. 3, pp. 35-48.

Bebeau, M.J., Rest, J.R. and Yannoor, C.M. (1985), "Measuring dental student's ethical sensitivity", Journal of Dental Education, Vol. 49, pp. 225-35.

Bernardi, R.A. (1994), "Fraud detection: the effect of client integrity and competence and auditor cognitive style", Auditing: A Journal of Practice \& Theory, Vol. 13, pp. 68-84.

Bernardi, R.A. (2004), "Commentary suggestions for providing legitimacy to ethics research", Issues in Accounting Education, Vol. 19 No. 1, pp. 145-6.

Bok, D.C. (1988), “Can higher education foster higher morals?”, Business and Society Review, Vol. 66, pp. 4-12.

Brooks, L.J. (2004), Business and Professional Ethics for Directors, Executives, and Accountants, 3rd ed., South-Western University Publishing, Cincinnati, OH.

Clikeman, P.M. (2003), "Educating for the public trust", The CPA Journal, August, p. 80.

Clikeman, P.M. and Henning, S.L. (2000), "The socialization of undergraduate accounting students", Issues in Accounting Education, Vol. 15 No. 1, pp. 1-17.

Deshpandé, S. (1996), "Ethical climate and the link between success and ethical behaviour: an empirical investigation of a non-profit organisation", Journal of Business Ethics, Vol. 15 No. 3, pp. 315-20.

Douglas, P.C., Barker, R.T. and Schwartz, B.N. (1995), "An exploratory study of accounting students' professional attitudes”, Research on Accounting Ethics, Vol. 1, pp. 315-30.

Earley, C.E. and Kelly, P. (2004), "A note on ethics educational interventions in an undergraduate auditing course: is there an 'Enron effect'?”, Issues in Accounting Education, Vol. 19 No. 1, pp. 53-62.

Elias, R.Z. (2004), "The impact of corporate ethical values on perceptions of earnings management", Managerial Auditing Journal, Vol. 19 No. 1, pp. 84-98.

Gaa, J.C. (1995), "Moral judgment and moral cognition”, Research on Accounting Ethics, Vol. 1, pp. 253-65.

Gaa, J.C. and Thorne, L. (2004), "An introduction to the special issue on professionalism and ethics in accounting education”, Issues in Accounting Education, Vol. 19 No. 1, pp. 1-6.

Gandz, J. and Hayes, N. (1988), "Teaching business ethics”, Journal of Business Ethics, Vol. 7, pp. 657-69.

Gardner, H. (2007), “The ethical mind”, Harvard Business Review, March, pp. 51-6.

Giacomino, D.E. (1992), "Ethical perceptions of accounting majors and other business majors: an empirical study”, Accounting Educators' Journal, Vol. 5, pp. 1-26.

Gravetter, F.J. and Wallnau, L.B. (2004), Statistics for the Behavioral Sciences, 6th ed., Wadsworth/Thomson Learning, Belmont, CA/Boston, MA.

Hair, J.F., Black, W.C., Babin, B.J., Anderson, R.E. and Tatham, R.L. (2006), Multivariate Data Analysis, 6th ed., Pearson/Prentice-Hall, Englewood Cliffs, NJ.

Hooks, K.L. and Tyson, T. (1995), "Gender diversity driven changes in the public accounting workplace: a moral intensity analysis”, Research on Accounting Ethics, Vol. 1, pp. 267-89. 
Humphrey, C. (2005), "In the aftermath of crisis: reflections on the principles, values and significance of academic inquiry in accounting: introduction", European Accounting Review, Vol. 14 No. 2, pp. 341-51.

IFAC (2003a), "Rebuilding public confidence in financial reporting: an international perspective", Report of the task Force International Federation of Accountants.

IFAC (2003b), "International education standard (IES 4)", Professional Values, Ethics and Attitudes, available at: www.ifac.org (accessed October).

IFAC (2005), Code of Ethics for Professional Accountants, available at: www.ifac.org (accessed June).

IFAC (2006), "Information paper", Approaches to the Development and Maintenance of Professional Values, Ethics and Attitudes in Accounting Education Programs, International Federation of Accountants, New York, NY, August.

Jennings, M.M. (2004), "Incorporating ethics and professionalism into accounting education and research: a discussion of the voids and advocacy for training in seminal works in business ethics", Issues in Accounting Education, Vol. 19 No. 1, pp. 7-26.

Jones, T.M. (1991), "Ethical decision making by individuals in organisations: an issue contingent model", Academy of Management Review, Vol. 16 No. 2, pp. 366-95.

Kohlberg, L. (1969), "Stage and sequence: the cognitive developmental approach to socialization", in Goslin, D.A. (Ed.), Handbook of Socialization Theory and Research, Rand McNally, New York, NY, pp. 347-480.

Lee, T. (1995), "The professionalization of accountancy: a history of protecting the public interest in a self-interested way", Accounting, Auditing \& Accountability Journal, Vol. 8 No. 4, pp. 48-69.

Leung, P. and Cooper, B.J. (2005), "Accountants, ethical issues and the corporate governance context”, Australian Accounting Review, Vol. 15 No. 1, pp. 79-88.

McPhail, K. (2001), "The other objective of ethics education: re-humanising the accounting profession - a study of ethics education in law, engineering, medicine, and accountancy", Journal of Business Ethics, Vol. 34, pp. 279-98.

Parker, L.D. (1994), "Professional accounting body ethics: in search of the private interest", Accounting Organizations and Society, Vol. 19 No. 6, pp. 507-25.

Parker, L.D. (2005), “Corporate governance crisis down under: post-Enron accounting education and research inertia", European Accounting Review, Vol. 14 No. 2, pp. 383-94.

Petrecca, L. (2002), "Conduct enters the curriculum: law business schools respond to scandals, revamp”, Crain's New York Business, September 23.

Ponemon, L.A. (1993a), "The influence of ethical reasoning on auditors' perceptions of management's competence and integrity", Advances in Accounting, Vol. 11, pp. 1-29.

Ponemon, L.A. (1993b), "Can ethics be taught in accounting?", Journal of Accounting Education, Vol. 11, pp. 185-209.

Ponemon, L.A. (1995), "The objectivity of accountants' litigation support judgements", The Accounting Review, Vol. 70 No. 3, pp. 467-88.

Ponemon, L. and Gabhart, D.R.L. (1990), "Auditor independence judgements: a cognitive developmental model and experimental evidence", Contemporary Accounting Research, Vol. 7 No. 1, pp. 227-51.

PricewaterhouseCoopers (2003), Educating for the Public Trust: The PricewaterhouseCoopers Position on Accounting Education, PricewaterhouseCoopers LLP, London, available at: www.pwc.com/images/us/eng/careers/car-inexp/EducatingPublicTrust.pdf 
St Pierre, K.E., Nelson, E.S. and Gabbin, A.L. (1990), "A study of the ethical development of accounting majors in relation to other business and nonbusiness disciplines", The Accounting Educators' Journal, Vol. 3, pp. 23-35.

Schweiker, W. (1993), "Accounting for ourselves: accounting practice and the discourse of ethics”, Accounting Organizations and Society, Vol. 18 Nos 2/3.

Shaub, M.K. (1994), "An analysis of the association of traditional demographic variables with the moral reasoning of auditing students and auditors", Journal of Accounting Education, Vol. 12 No. 1, pp. 1-26.

Sinclair, A. (1993), "Approaches to organisational culture and ethics”, Journal of Business Ethics, Vol. 12, pp. 63-73.

Smith, M.L. (2003), "A fresh look at accounting ethics (or Dr Smith goes to Washington)", Accounting Horizons, Vol. 17 No. 1, pp. 47-9, Guest editorial.

Stape, A.L. (2002), "Ethics: area business schools are not rushing to add courses on ethical behaviour as a result of the Enron scandal", The Providence Journal, April 7.

Swanson, D.L. (2005), "Business ethics education at bay: addressing a crisis of legitimacy”, Issues in Accounting Education, Vol. 20 No. 3, pp. 247-53.

Sweeney, J.T. and Roberts, R.W. (1997), "Cognitive moral development and auditor independence", Accounting Organizations and Society, Vol. 22 Nos 3/4, pp. 337-52.

Thorne, L. (1999), "An analysis of the association of demographic variables with the cognitive moral development of Canadian accounting students: an examination of the applicability of American based findings to the Canadian context", Journal of Accounting Education, Vol. 17, pp. 157-74.

Victor, B. and Cullen, J.B. (1988), "The organizational bases of ethical work climates", Administrative Science Quarterly, Vol. 33 No. 1, pp. 101-25.

Welton, R.E., LaGrone, M. and Davis, J.R. (1994), "Promoting the moral development of accounting graduate students: an instructional design and assessment", Accounting Education: An International Journal, Vol. 3 No. 1, pp. 35-50.

Wimbush, J. and Shepard, J. (1994), “Toward an understanding of ethical climate: its relationship to ethical behaviour and supervisory influence", Journal of Business Ethics, Vol. 13, pp. 637-47.

Wimbush, J., Shepard, J. and Markham, S. (1997), “An empirical examination of the relationship between ethical climate and ethical behaviour from multiple levels of analysis", Journal of Business Ethics, Vol. 16, pp. 1705-17.

Windsor, C.A. and Ashkanasy, N.M. (1995), "The effect of client management bargaining power, moral reasoning development, and belief in a just world on auditor independence", Accounting Organizations and Society, Vol. 20 Nos 7/8, pp. 701-20.

\section{Further reading}

Leung, P. and Cooper, B.J. (2006), "Editorial to special edition", Australian Accounting Review, Vol. 38 No. 1, pp. 1-2.

\section{Corresponding author}

Beverley Jackling can be contacted at: beverley.jackling@rmit.edu.au 